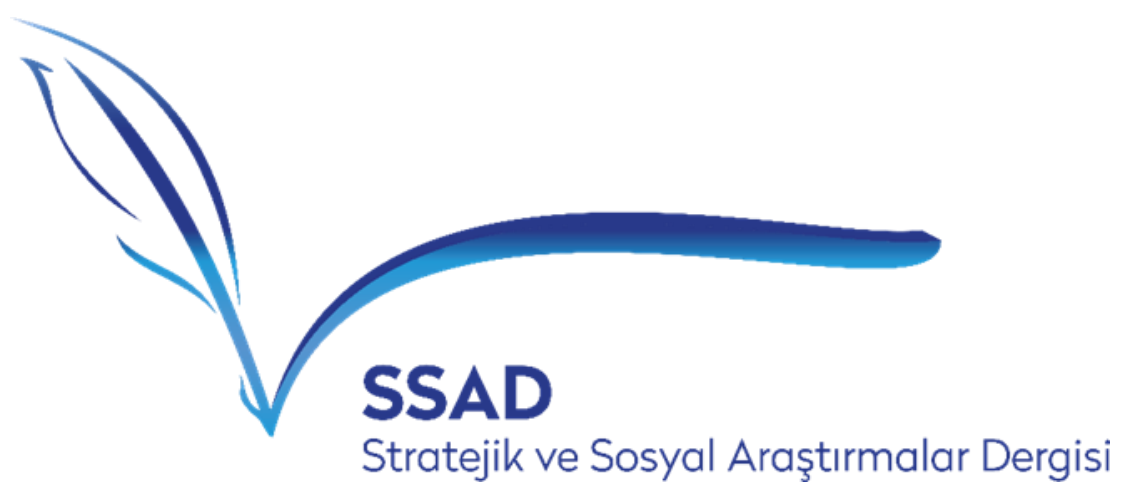

ISSN: $2587-2621$

Volume 4 Issue 3, November 2020

ORCID ID: 0000-0001-6061-8388

Makale Gönderim Tarihi: 21.08.2020

Makale Kabul Tarihi: 29.09.2020

DOI: $10.30692 /$ sisad.783545

\title{
ALMAN KİMLİĞİ: KÜLTÜREL ANTROPOLOJIKK BİR BAĞLAM DENEMESİ
}

\section{German Identity: A Cultural Anthropological Context Study}

\author{
Samet ZENGINOĞLU \\ Dr. Ögr. $\ddot{\text { Uyesi }}$ \\ Adiyaman Üniversitesi \\ Sosyal Bilimler Meslek Yüksek Okulu, Dış Ticaret Bölümü \\ szenginoglu@adiyaman.edu.tr
}

\begin{abstract}
Özet: Almanya, Avrupa tarihi için olduğu kadar dünya tarihi için de düşünsel, sanatsal ve ekonomik perspektiflerin özgün alanlarından birisini temsil etmektedir. Bu alan içerisinde Alman kimliği inşa sürecine bakıldığında dil ve kültür öğelerinin önemli bir boyuta sahip olduğu düşünülmektedir. Her ne kadar Alman milliyetçiliği ile Nasyonal Sosyalizmin iç içe geçtiği 1930'lu yıllar ırk temelli bir perspektifi ortaya koymuş olsa da genel tablo dahilinde kültürel öğelerin belirleyiciliği de göz ardı edilemez bir etkiye sahip olmuştur. Dolayısıyla bu çalışma da ilgili öğelerin analiz edilmesini amaç edinmiştir. Bu amaç kapsamında kültürel antropolojik zemin üzerinden hareket edilmiştir. Alman kimliğinde "biz" ve "öteki" tanımlamalarına dair tarihsel ve güncel odak noktaları kültürel kodlar üzerinden değerlendirilmiştir. Özellikle göçmen konusu ile birlikte bu kodların belirginleşmesi önem arz eden bir gelişme olarak görülmüştür.
\end{abstract}

Anahtar Kelimeler: Kimlik, Alman Kimliği, Kültürel Antropoloji, Öteki. 


\begin{abstract}
Germany represents one of the unique aspects of an intellectual, artistic and economic perspective not only for the European history but also for the world history. When the construction of German identity is examined, it is considered that both the language and culture play an important role. Although during the 1930s, the German nationalism and National Socialism were intertwined and represented a racist perspective, in general, the impact of the cultural motives cannot be ignored. Therefore, the aim of the study is to examine the relevant elements. The analysis in the study has been conducted at a cultural anthropological level. The historical and contemporary concepts "us" and "the other" in German identity have been investigated through cultural codes. The clarification of these concepts has been considered as a significant development, especially when the issue of immigration is considered.
\end{abstract}

Keywords: Identity, German Identity, Cultural Anthropology, The Other.

\title{
GíRiş
}

Kimlik konusu, sosyal bilimlerin temel tartışma alanları içerisinde yer almaktadır. Özellikle Soğuk Savaş dönemi sonrasında küreselleşme, postmodernizm, konstrüktivizm gibi anahtar kelimeler ekseninde de bu alanın çok-boyutlu ve daha kapsamlı bir biçimde analiz edildiği/değerlendirildiği görülmektedir. 1993 yılında yürürlüğe giren Maastricht Antlaşması ile de gündeme gelen Avrupa vatandaşlığı ve "çeşitlilik içinde birlik" gibi söylem ve hamlelerle de Avrupa Birliği bu tartışmaların çeşitli etkilerinin görüldüğü bir aktör olmuştur. Zira, yükselen popülizm, göç faktörü, güvenlik, ekonomik kriz gibi başlıklar dahilinde mikro ve makro ölçekte Avrupa, kimlik odaklı krizlerle karşılaşmaktadır.

Almanya'nın da kuşkusuz bu süreçten kendini uzak tutması ya da soyutlaması mümkün görünmemektedir. Bu düşünceyi, Almanya açısından müşahede edilen göç, kültür ve kimlik eksenli tartışmalar ve gelişmeler büyük oranda teyit etmektedirler. Çalışma, bu gelişmelerin kimlik açısından ne tür tezahürleri olduğu sorunsalından hareket ederek kaleme alınmıştır. Ancak Almanya tarihindeki kodların giriftliği çalışmanın temel savını inşa etme noktasında birtakım soruları beraberinde getirmiştir. Örneğin tarihsel eksende "Avusturya", "Prusya" ve özellikle "Almanya" adlandırmalarının tarifi güçtür. Çünkü sürekli toprakları ve kurumları değişen, aralarında ve Avrupa'nın geri kalanı ile ilişkilerinde yön değişiklikleri yaşayan siyasi varlıklar söz konusu edilmektedir (Breuilly, 2020: 25).

Coğrafi ve politik sahanın yanı sıra düşünsel yaratım ve özellikle 1930'lardaki düşünsel ve politik yıkım da ifade edilen tabloyu derinleştirmektedir. Fulbrook'un ifadesi ile (2018: 15) "çok geç birleşmiş ve bu işte çok geç kalmış bir ulus; ruhsal alanın özgürlügünü kamusal alandan ve devletin iktidarından ayıran "düşünürlere ve şairlere" sahip bir ulus; edebiyata ve müziğe katkıları ne olursa olsun, en sonunda, Adolf Hitler'in soykırıma dayalı yönetimini bir kötülük simgesi olarak ortaya çıkarmakla ünlenen bir ulus." Dolayısıyla benzersiz yaratıcılık ve benzersiz yıkıcılığın aynı odakta yer alabildiği bir ülkenin kimlik inşa süreci ve bu süreçteki "öteki" imgesinin teşhisi ve analizi birtakım zorlukları beraberinde getirmektedir.

Çalışma, bu zorlukları göz ardı etmeksizin Alman kimliği inşasında kültürel öğelerin belirleyici olduğu alanları analiz etme amacını taşımaktadır. Bu kapsamda özellikle dil ve çokkültürlülük konularına odaklanan kültürel antropolojinin bağlamı dikkate alınmakta ve bu husus çalışmanın birinci bölümünü teşkil etmektedir. Tarihsel perspektiften XX. yüzyıla Alman kimliğinde dil ve düşünce temelinde "biz"in oluşturulduğu/oluşturulmaya çalışıldığı ikinci bölümde ise ilgili bağlama dair vetireler ele alınmaktadır. Üçüncü ve son bölümde ise özellikle XX. yüzyılın ikinci yarısından bugüne göçmenler özelinde ekonomi, güvenlik ve politik eksenli yansımalara sahip “öteki” algisına yer verilmektedir. 


\section{KÜLTÜREL ANTROPOLOJIKK BAĞLAM VE KİMLİK}

Antropoloji terimi, Yunanca "insan" anlamına gelen "Antropos" ve "(n)ın çalışması" anlamına gelen "logia" kelimelerinin birleşmesinden oluşmuştur (Lavenda ve Schultz, 2019: 24). Antropolojinin kökenleri, Heredetos'a değin uzanmaktadır (Eriksen ve Nielsen, 2013). Fakat özellikle XVI. yüzyıldan itibaren gerçekleşen yeni coğrafyalara ulaşma süreci ve sonrasında sömürgecilik konusunda yapılan literatür çalışmaları ile antropoloji bilimi filizlenmeye başlamıştır (Bostan, 2016: 3). Dolayısıyla bu süreç ve bağlam göz önünde bulundurulduğunda, esas itibariyle antropolojinin bir bilim olarak gündeme gelmesini Batıl1-olmayan "öteki”ni tanıma, anlama ve açıklama girişimi olarak değerlendirmek mümkündür (Özbudun ve Uysal, 2019: 20; Sarukkai, 1997).

En geniş anlamıyla antropoloji, kendini "insan fenomenini” incelemeye adamış disiplindir (LeviStrauss, 2018: 16) ve bütün yer ve zamanlarda bu fenomeni değerlendirmektedir (Haviland vd., 2008). $\mathrm{Bu}$ inceleme/değerlendirme ekseninde antropoloji, benzerliklerini ve farklılıklarını anlayabilmek amacıyla insanı ve insan toplumlarını tüm yönleriyle ele almaktadır. Bu kapsam ise bütüncül ve karşılaştırmalı bir perspektife sahiptir (Özbudun ve Uysal, 2019: 24). Bu tanımlamalar ile birlikte antropoloji dört temel alanı kapsamaktadır. Bunlar; (a) fiziksel antropoloji, (b) arkeoloji, (c) dilbilimsel antropoloji ve (d) kültürel antropolojidir (Haviland vd., 2008).

"Ben" ya da "biz" karşısındaki "öteki”, farklılıkları itibariyle antropolojinin temel odak noktasını teşkil etmektedir. Bu farklılıklar, yukarıda zikredilen temel alanlar nazarında açıklanmaktadır. Öyle ki, bazı farklılıklar, eşitsizliği ifade eden yaklaşımları da içermektedir. Bilindiği üzere, yeni coğrafyaların (yeniden) keşfi sonrasında yaşanan gelişmeler, ötekileştirme açısından ortaya çıka(rıla)n eşitsiz tabloya dair argümanlara ve emarelere sahip olmuştur. Bazı yaklaşımlara göre, insan toplulukları genetik mirasları dolayısıyla birbirlerinden farklı oldukları için, aşılmaz bir uçurum söz konusudur. Zira genetik miraslar arasında, zihinsel becerileri ve ahlaki tavırları etkileyen bir eşitsizlik vardır. Nitekim ırkçıların tezi bu eksende yer almıştır (Levi-Strauss, 2018: 77). Bu sebepten dolayıdır ki, antropoloji ulus ve/veya ırk inşa süreçleriyle ilişkilendirilmiştir (Özbudun ve Uysal, 2019: 15). Bu hususun da doğrudan kimlik tartışmalarına etki etmiş olduğu göz ardı edilemez bir gerçektir.

XX. yüzyıla gelindiğinde, Franz Boas'ın etkisiyle (1858-1942), antropologlar farklı insan gruplarını birbirinden ayıran çeşitli inançların ve uygulamaların ırktan kaynaklanan biyolojik farktan değil, sosyal öğrenmedeki farklılıklardan kaynaklandığını göstermek için kanıtlar toplamışlardır (Lavenda ve Schultz, 2019: 42. Ayrıca bkz. Boas, 2017). Bir adım sonrasında kültürel antropolojik bağlama odaklanmak olanaklıdır. Wulf'a göre (2015: 136), kültürel antropoloji, ötekiliğin soru(n)ları ile ilgilenen ötekinin bilimi olarak anlaşılabilir ve bu konular gerek sanatın gerekse de sosyal bilimlerin merkezinde yer almaktadır.

İfade edilen bağlamda, Soğuk Savaş sonrası dünya çapında güçlenen etnik köken ve milliyetçilik, ulus ötesi işgücü göçü, toplumsal cinsiyet ve cinsellik gibi günümüz araştırma konuları da kültürel antropologların inceleme alanlarını ihtiva etmektedirler (Lavenda ve Schultz, 2019: 27). Özellikle 11 Eylül saldırıları sonrası ortaya çıkan güvensiz ortam kültürel kodlar nazarında önem arz eden bir yapı ortaya çıkarmıştır. Bu türden belirsizlik ve güvensizlik durumlarını yönetmek için verilen mücadele de bazen kimlik politikalarını gündeme getirmiştir. Mücadele, ulus devletin vatandaşları olarak grupların genellikle ortak bir kimliğe karşıt inşa edilen ve ekseriyetle daha dar tanımlanan ve dışlayıcı bir eksene sahip siyasi ittifak yaratma ve sürdürme alanını kapsamaktadır (Lavenda ve Schultz, 2019: 259). Zira "bizden olmayan" olarak değerlendirilen ve deklare edilen "öteki”ye karşı geliştirilen bir savunma mekanizması söz konusu olmakta ve bu mekanizmayı deyim yerindeyse ayakta tutan paradigmalardan birisi de kültürel faktörler olmaktadır.

XXI. yüzyılın başlangıcında yer alan kimlik odaklı tartışmalar ve Avrupa özelinde bu tartışmaların yansımaları açısından bu mücadele alanı önemli ipuçları barındırmaktadır. Örneğin çokkültürlülük perspektifindeki çalışmalar ve tartışmalar bu açıdan dikkat çekmektedir. Zira 
kültürel antropoloji de farklı toplumları, farklı kültürleri her boyutuyla inceleyen oldukça geniş bir alana sahip bir disiplin olduğu için çokkülttürlülük de antropolojinin çalışma alanı içinde değerlendirilmektedir (Çarpar, 2012: 57; ayrıca bkz. Turner, 1993). XX. yüzyılın sonlarından bugüne gerek Avrupa genelinde gerekse de Almanya özelinde çokkültürlülük tartışmalarının söz konusu olduğu ise bilinmektedir (Eckardt, 2007).

$\mathrm{Bu}$ genel çerçeve dahilinde, milliyetçilik, din, eğitim konuları başta olmak üzere, ulus ötesi göç hareketleri ve bu hareketlerin neden ve sonuçları kültürel antropoloji bağlamında analiz edilebilecek hususlar arasında yer almaktadırlar. Dolayısıyla bu bağlamın da Alman kimliği nazarında önemli bir konumda yer aldığı düşünülmektedir. Bu sebeple, tarihsel perspektiften bu yüzyıla bu bağlam eksenindeki kimlik ve dolayısıyla "öteki" inşasının nasıl yansımalara sahip olduğunun değerlendirilmesi gerekmektedir.

\section{TARİHSEL PERSPEKTİFTEN XX. YÜZYILA ALMAN KİMLİĞí}

Bu bölümün amacı, Alman kimliği inşası sürecindeki kültürel argümanların teşhis ve tespit edilmesidir. Tarihi eksende, şu anda Almanya olarak bilinen bölgede tarihöncesi çağlardan bu yana yerleşimler olduğuna dair kanıtlar bulunmuştur (Fulbrook, 2018: 23). Bu kanıtlarla birlikte, çalışma açısından dikkat çeken husus başlangıca dair vetirelerde dil faktörünün ön plana çıkmış olmasıdır. M.Ö. 500 yıllarında Güney İskandinavya ya da en Kuzey Almanya'da yoğunlaşan Demir Çağı kulübelerinde Avrupa'nın Hint-Avrupa nüfusunun bir kolunun bazı sessiz harfleri başka yerlerde yaşayan herkesten farklı biçimde telaffuz ettiği tespit edilmiştir. Yeni sesleri kullanmaya başlayan bu kabileler ön-Germenler olarak bilinmektedirler (Hawes, 2019: 11-12; ayrica bkz. Solsten, 1996). Dil konusunda bir adım ileride, Almanya'nın modern Avrupa devletleri arasında, ismini bir kavim veya bölgeden değil, bilakis konuşulan dilden alan tek devlet olduğu gerçeği ön plana çıkmaktadır (Fulbrook, 2018: 27).

Hatta Alman kimliği açısından bir kırılma noktası teşkil eden Reform sürecine dair de bu gerçek bir kez daha görülmektedir. Öyle ki Martin Luther (1483-1546) tarafindan 1520'de İncil'in Almanca'ya çevrilmesi bu manada özel bir konumda yer almaktadır (Hawes, 2019: 81). Aydınlanma Çağı adına gerek Avrupa gerekse de Alman tarihi için önem arz eden XVIII. yüzyıl sonlarında Almanya' da şaşırtıcı bir edebi canlanma yaşanırken Almanca'nın da edebi bir dilin ve zengin bir ifadenin aracı olarak yeniden doğmuş olması yine bu bağlamda eklenmesi gereken hususlar arasindadır (Fulbrook, 2018: 93; Becker-Cantarino, 2005). Bir yüzyıl sonra Reich Anayasasının (1877) 186. paragrafina göre mahkemelerde konuşulan tek dil Almanca olmuştur (James, 1999: 100). Dolayısıyla Alman kimlik inşasında dil konusunun etkisi görülmektedir. Nitekim bu etkinin sürekliliği, dil, kültür ve çokkültürlülük tartışmaları açısından XX. yüzyılın ikinci yarısından bugüne değin de söz konusu olacaktır.

Alman tarihine dair dil odaklı başlangıçla birlikte, Almanya tarihini bir kısım tarihçiler Charlemagne'ın batıda bir "Roma" imparatorluğunu tekrar kurmasıyla başlatmaktadırlar (Fulbrook, 2018: 25). Lakin X. yüzyıldan itibaren modern Almanya'nın öncüsü olarak da addedilen Kutsal Roma Germen İmparatorluğu için kimlik ekseninde çok belirgin bir inşa sürecinden söz etmek güç görünmektedir. Breuilly'e göre (2020: 23), gayet açık bir biçimde yüzlerce siyasi birime bölünen Kutsal Roma İmparatorluğu bir devlet değildir. Ancak devlet, kendi mensupları arasında ve yönetenlerle tebaaları arasındaki anlaşmazlıkları çözecek kurumları sağlayan bir hukuk ya da barış düzeni olarak görülmüştür. Benzer şekilde Fulbrook da (2018: 40) XVI. yüzyıla gelindiğinde Kutsal Roma İmparatorluğu'nun siyasal hayatının fazlasıyla karışık olduğunu ifade etmektedir.

Bununla birlikte, XVI. yüzyıldan itibaren belirgin bir biçimde görülmeye başlanan Alman-Fransız rekabetinin etkisi ve Fransız İhtilali'nin Avrupa ülkelerindeki yansımaları ile birlikte XVIII. yüzyıldan itibaren Alman kimliği inşasında milliyetçilik formu yeni bir boyuta sahip olmuştur. Bu boyut entelektüel bir zemin de kazanmıştır. Johann Gottfried Herder (1744-1803) ve Johann 
Gottlieb Fichte (1762-1814) bu bağlamda ön plana çıkan düşünürler arasında yer almışlardır (İplikci, 2017; Waldow ve DeSouza, 2017; Yıldırım, 2011). İlk olarak Herder'in adıyla anılan bir "kültürel milliyetçilik" biçiminden söz etmek mümkündür. Bu husus, çalışmanın odak noktası açısından dikkat çekmektedir. Çünkü inşa edilen bu milliyetçilik Fransız karşıtlığı ekseninde dil ve kültür faktörlerini temel almaktadır. Dolayısıyla her ne kadar Almanya-Fransa karşıtlı̆̆ ekonomik ve politik çıkarlar ekseninde analiz edilse de bu perspektif esas itibariyle kültürel bağlamı ortaya koymaktadır. Fransız dil ve kültürünün daha önceki hakimiyetine karşı çıkan Herder, bir kültürel topluluk, (siyasal birim, devletle aynı olmayan) bir volk fikri üzerinde durmuştur ve her kültürün kendi açısından geçerli ve organik bir bütün olarak görülmesi gerektiğini öne sürmüştür (Fulbrook, 2018: 99-100). Kültürel eksende bir "öteki” üzerine inşa edilen bu kimlik milli uyanışla beraber hareket etmiştir. Hatta burada belirgin bir dil vurgusu da söz konusu olmuştur. Bu dönemde dilsel bir Almanlığı savunanlar vardır ve Herder'in 1772'de Berlin'de yayımlanan eseri Essay on the Origins of Language'de bu savunu kendisine yer bulmuştur (James, 1999: 47).

Fransız etkisi, Almanya üzerinde XIX. yüzyılın başlangıcından itibaren artmış ve 1806 yılında Kutsal Roma Germen İmparatorluğu'nun Napolyon Savaşları ile ortadan kalkması sonucundaki Fransız egemenliği dönemi hem Fransız karşıtlığının hem de modern Alman milliyetçiliğinin oluşumuna zemin hazırlamıştır. Örneğin, Fichte'nin 1808 yılında Berlin'de verdiği konferanslar, "Alman Milletine Söylevler" güçlü bir milliyetçiliği dile getirmiştir. Fransızlar fetheden olduğu için değil yabancı olduğu için reddedilmiş ve ortak kültürel aidiyete dayalı milliyetçilik vurgulanmıştır (Breuilly, 2020: 36). Belirtmek lazımdır ki esas itibariyle Alman milliyetçiliği hiçbir siyasal içeriği olmayan, kültürel bir toplumun ifadesi olarak ortaya çıkmıştır. Lakin Fransız devrimine ve Napolyon savaşlarına karşılık siyasal bir içerik kazanmıştır (James, 1999: 260-261). $\mathrm{Bu}$ gelişmelere karşın Herder ve Fichte örnekleri ile de birlikte XIX. yüzyılın başlarında ulusal birliğin tamamlanma evresi öncesinde Alman milliyetçiliğinin geniş kitlelere ulaşmadığ 1 görülmektedir. Zira milliyetçilik düşüncesi daha çok entelektüel bir çevre tarafından şekillendirilmiştir. $\mathrm{Bu}$ düşüncenin ivme kazanmasında ise şüphesiz Fransız hegemonyasını genişletme politikasıyla Napolyon önderliğinde yürütülen savaşların etkisi olmuştur (Doğan, 2019: 5). Fakat bir kez daha belirtilmelidir ki bu karşıtlık salt ekonomi-politik bir alan ihtiva etmemiştir. Kültür ve düşünce sahasında da bu karşıtlığın belirgin izleri mevcuttur. Öyle ki, örneğin aklın ve bireyin merkeze alındığ 1 ve kutsandığ Fransız rasyonalitesine karşı, Alman düşüncesi tabiatın ruhunu referans almıştır (Doğan, 2019: 11-12).

Bu noktada, Fransa faktörü belirgin biçimde ön planda yer almıştır. Napolyon egemenliği milli direnci uyandırmıştır (bkz. Dorpalen, 1969). 1815'ten itibaren milli duygular, politika geliştirme süreçlerini etkilemiş ve hatta doğrudan belirlemiştir (Breuilly, 2020: 28). 1869 y1lında Alman birliğinin şiddet kullanarak sağlanacağını açıklamış olan Bismarck, bu bağlamda bir yıl sonra bu dönem kendisine rakip olarak gördügü Fransa'ya da savaş ilan etmiştir. (akt. Doğan, 2019: 6). Bismarck'nın temel amacı Almanya'nın konumunu yeni bir savaşa girmeden güçlendirmek olmuştur. Başlıca potansiyel düşman ise Fransa'dır (Fulbrook, 2018: 135). Her ne kadar Fransa'ya duyulan hayranlık (James, 1999: 24) söz konusu edilse de kimlik inşa sürecindeki "öteki”ne dair hayranlık ve tehdit/şüphe ikilemini doğal kabul etmek olasıdır.

Çeşitli yaklaşımlar ve politik perspektifler dahilinde görüldüğ̈ üzere, ulusal bir misyon doktrininin geliş(tiril)mesi, 1871'de bir Alman devletinin kurulması öncesinde de bir zemine sahiptir (James, 1999: 17). 1871 tarihi Almanya tarihi için önem arz etmektedir. Çünkü 18 Ocak 1871 'de Versailles'daki bir törende, Alman İmparatorluğu'nun kurulduğu ilan edilirken Alman devletlerinin hükümdarları, Prusya Kralı I. Wilhelm'e birleşmiş Almanya'nın tacını sunmuşlardır (Fulbrook, 2018: 130) ve Avrupa güç dengesi yeni boyut kazanmıştır. Bunun yanı sıra bu dönemden itibaren Alman kimlik inşasında kan bağı ilkesinin (Pamuk, 2019: 77) belirgin bir biçimde gündemde yer tutması önem arz etmektedir. Nitekim temelleri ekonomik saiklere dayansa da kan bağı nazarının da etkisi ile 1873 yılına ait antisemitizm krizi bu açıdan değerlendirilebilmektedir (Fulbrook, 2018: 133). Ekonomik saiklerin kimlik ile ilişkisi bu açıdan 
dikkat çekici bir diğer husustur. Çünkü Ortaylı'ya göre (2019: 16) XIX. yüzyılda yeni endüstri imparatorluğu güçlendikçe Alman milliyetçiliği bu yeni birliğin harcı olmuştur. Dolayısıyla yükseliş trendi gösteren Alman milliyetçiliği ve milli bilinç uyanış1 XIX. yüzyıldan itibaren temel odak noktasını teşkil etmiş ve hatta bu odak Alman kültüründe imaj çalışmalarında da kendisine yer bulmuştur (Öztürk, 2015: 17). Bu yükselişin XX. yüzyılın ilk yarısından itibaren ise çok farklı bir boyuta evrildiği görülecektir.

\section{XX. YÜZYILDAN XXI. YÜZYILA: KÜLTÜREL ARGÜMANLARIN YÜKSELISŞI}

Almanya ile ilgili olarak giriş bölümünde ifade edilen benzersiz yıkıcılık ve yine bir o kadar benzersiz yaratıcılık ifadesi kendisini XX. yüzyılda belirgin bir biçimde göstermiştir. İki dünya savaşı arası dönemde yaşanan gelişmeler bu etkinin göstergelerini taşımaktadır. XIX. yüzyıla değin Alman kimliğinde kültürel faktörlerin varlığı gözlemlense de Almanya'nın birleşmesi sonrasında daha keskin ayrımların ortaya çıktığı görülecektir. Bilindiği üzere modern ulusal kimlikler, "öteki” tanımlamasının yapılması ile oluşmaktadır. Bununla birlikte modern Alman ulusallık anlayışı, etnik kimliğe dayalı ve etnik aidiyet temelinde halk (Volk)-merkezli ve farkl11ıç̧ı olmuştur (Pamuk, 2019: 74). Bahsi geçen ayrım(c1lık) 1930'lardan itibaren Alman kimliğinde antisemitizmin yükselişinde tezahür etmiştir. 1933 tarihli "Profesyonel Memuriyet Yasası" başta olmak üzere Yahudiler devlet bürokrasisinden dışlanmış (James, 1999: 165) ve insanlık tarihi adına onulmaz izler bırakan hadiselere şahit olunmuştur. Temelleri 1873'teki antisemitizm krizine değin ulaşan gelişmeler dikkate alındığında, bu noktada Heinrich von Treitschke'nin daha çok kısaltılmış biçimi Yahudilerimiz Hakkında Bir Söz başlığıyla bilinen 1879 tarihli makalesi Beklentilerimiz'in modern politik antisemitizmin kurucu belgesi olarak deklare edilmesi de eklenmelidir (Hawes, 2019: 132).

Buna karşın, 1945'teki askeri yenilgi ile beraber Alman milliyetinin siyasal tezahürü yıkılmış ve Alman milliyetçiliği itibarını yitirmiştir. Zira 1933'den 1945'e dek ulus ile Nasyonal Sosyalizm eşanlamlı olarak kullanılmıştır (James, 1999: 149). II. Dünya Savaşı sonrası ve Soğuk Savaş dönemi ile birlikte Almanya bu kez yıkıcılık boyutunun tersine evrilmiş ve gerek ekonomik gerekse de politik yeni bir ivme alanı oluşturmuştur. İkiye bölünmüş Almanya sathında Almanya Federal Cumhuriyeti ekseninde bu ivmeyi görmek olasıdır. Bununla birlikte savaş sonrası ortaya çıkan ekonomik, demografik ve politik kriz faktörlerinin etkisi ile XX. yüzyılın ikinci yarısından itibaren Almanya'ya gerçekleşen işgücü göçü kimlik-kültür ekseninde Almanya için yeni bir boyutu da ifade etmiştir. 1950'li yıllara gelindiğinde ulus ötesi kitlesel göçler, nüfus hareketleri, küreselleşme gibi faktörler yoluyla homojen olan toplumlar heterojen bir yapıya bürünmüş ve çokkültürlü bir nitelik kazanmışlardır (Pamuk, 2019: 75). Bu heterojen yapı içerisinde Alman kimliği yeni bir tartışma alanı içerisinde olmuştur. Zira göçmenlerin vatandaşlık statüsünün nasıl olacağı ve kimliklerinin ne tür tezahürlere sahip olacağı soruları gündeme gelmiştir. Atılan adımlar aracılığıyla ilgili soruların yanıtlarına ulaşmak mümkün olmuştur. Örneğin ilk kez 1965 yılında çıkarılan Yabancılar Yasası ile Alman vatandaşı olmayan yabancılar, sosyal ve medeni haklardan yararlanabilirken, siyasal haklardan faydalanamamışlardır. Her ne kadar 1990 ve 2001 yılındaki yasalar ile göçmenlerin statüsüne dair daha liberal gelişmelere rastlanmış olunsa da (Pamuk, 2019: 83-85) XXI. yüzyıla uzanan süreçte göç ve kimlik konusunun kültürel temelli sorunsallar ile olan ilişkisi varlığını devam ettirmişsir.

Göç konusu milli kimliğin oluşturulmasında geniş kapsamlı etkilere sahip olmuştur. Çünkü yerleşik milli kimlik ve toplumsal bağl11ık kavramlarının sorgulanmasına yol açabilmiştir -ki Almanya perspektifinde bu sorgulanmanın popülizmin kimlik inşasında çeşitli yansımalarına şahit olunmaktadır. Zira bazı topluluklar (PEGIDA) ya da partiler (AfD) için toplumun tam bir üyesi olarak kabul edilmek adına Almanya vatandaşlığına sahip olmak halen yeterli görülmemektedir. Dolayısıyla toplumun sözde farklı unsurları belirlenirken "sıradan Almanlarla" "göç geçmişi olan Almanlar" arasındaki ayrımın önemli bir rol oynadığını belirtmek yanlış 
olmayacaktır (Scherr, 2013: 2). Bu tablo da kültürel antropoloji-kimlik inşası ilişkisi nazarında Alman kimliğinin yüzleşme ve meydan okuma iklim ve ikilemini ortaya koymaktadır.

11 Eylül saldırıları sonrası oluşan güven(sizlik) eksenli konjonktür de XX. yüzyılın ikinci yarısından itibaren konumu zaten ihtilaflı olan göçmenlerin durumunu ve geleceğini yeniden sorgulanır hale getirmiştir. Dini kimliğin kültürel öğelerle olan bağlantısı da şüphesiz Avrupa için olduğu gibi Almanya için de "öteki”"nin yeniden inşasını kolay kılmışır. Bu noktada kimlik inşa sürecinin kültürel değerler üzerinden gerçekleşmesi, çalışma nazarında önemli ipuçlarına sahiptir. Nitekim 1930'lu yıllar Alman kimliğinin bu dini-kültürel kod karşısındaki boyutu da anlamlıdır. Öyle ki Almanya'nın uzun antisemitizm tarihine rağmen, Alman toplumunun Hiristiyan karakterinde bu denli 1srar edilmesi, genellikle ortak bir Yahudi-Hıristiyan mirasına referans ima etmekte, İslam'1 Alman kültüründen açıkça uzakta tutmaktadır (Nordbruch, 2011: 11). "Kültür" konusu Almanya için yeniden önemini koruyan hususların başında gelmektedir.

2010 yılının Ekim ayında Almanya Başbakanı Angela Merkel'in çokkültürlülüğün başarısız olduğu/iflas ettiği yönündeki söylemleri bu önemin bir sonucu olarak değerlendirilmektedir. Nitekim çalışmanın temel odak noktası açısından çokkültürlülüğün işlemesi için göçmenlerin daha fazla entegrasyon sürecine dahil olmaları gerektiğini ifade etmesi ve bunun da Almanca öğrenmek ile başlayacağı yönündeki ifadeleri şüphesiz dil ve kültür konusunun ehemmiyetini Alman kimliği açısından bir kez daha göstermiştir. Yine örneğin Türkiye özelinde sıç̧a rastlandığı üzere taraflardan birinin aile birleşimi nedeniyle Almanya'ya gitmesi gerekliliği durumunda, gidecek olan kişinin temel düzeyde Almanca bilmesi gerekliliği hukuki ya da politik bir detay olarak nitelendirilebilirse de kültürel açıdan ciddi bir mesaj olarak da nitelendirilebilecek bir diğer örneği teşkil etmektedir. Dolayısıyla genel bağlam ekseninde göçmenlere hak vermek yerine göçmenleri Almanlaştırma politikasına dair eleştirilerin dikkate alınması gerektiği düşünülmektedir (Ceylan, 2016: 1211).

\section{SONUÇ}

İdeoloji bağlamında kimlik tanımlamalarının yapıldığı Soğuk Savaş döneminin ardından kuramsal çalışmalar kültür eksenine odaklanmıştır. Özellikle din ve kültür odaklı çalışmalar ulus ötesi göç ve terörizm gibi başlıklar altında incelenmiştir. Bu tartışmalardan kendisini soyutlaması mümkün olmayan aktörlerin başında Avrupa Birliği gelmiştir. İşgücü göçü nazarında Avrupa Birliği'nin deyim yerindeyse lokomotifi konumunda yer alan Almanya da bu süreçten bizatihi etkilenmiştir. Çokkültürlülük açısından ifade edilen söylemler ve gerçekleştirilen politikalar bu sürecin çıktılarını oluşturmuşlardır. Dolayısıyla Alman kimliğinin bu boyutunun değerlendirilmesi amacı söz konusu olmuş ve bu amacın kuramsal zemini kültürel antropoloji üzerine inşa edilmiştir.

Alman kimliği, Alman milliyetçiliğinin XX. yüzyıldaki evrimi açısından kan bağı ve bir adım ötesinde 1rk temelli olarak değerlendirilmektedir. Ancak bu kimliği inşa eden tarihsel donelere bakıldığında kültürel kodların da büyük öneme sahip olduğuna şahit olunmaktadır. Çalışma açısından genel eksende altı vetire bu durumu destekler mahiyette olmuştur. İlk olarak başlangıca dair göstergelerin dil faktörüne odaklanmış olmasıdır. İkinci olarak yine dil faktörü ile ilgili ve ilişkili bir biçimde Alman kimliğini birçok noktada etkileyen Reform sürecinde Luther'in İncil'i Almanca'ya çevirmesi halen tartışılan ve üzerinde durulan hususlar arasında yer almaktadır. Zira ulus bilincinin nüvelerine dair adımlarla karşılaşılmaktadır.

Üçüncü olarak, Herder ve Fichte'nin düşünceleri ve görüşleri de entelektüel zemin açısından önemlidir. Hatta bu dönemde dilsel bir Almanlığın savunusu dikkat çekmektedir. Dil konusundaki kimlik inşasının sürekliliği söz konusu olmuştur. Dördüncüsü, Alman tarihi açısından XX. yüzyıla dek izler barındıran Fransa ve Fransız kimliğine karşıtlıktır. Burada kast edilen "öteki" politik ve ekonomik anlamda bir rakip olarak değerlendirilmektedir. Lakin bunun yanı sıra düşünsel/fikri zeminde de bir karşıtlı̆̆ın olduğu görülmektedir. Fransız rasyonalitesine 
karşı inşa edilen bir Alman fikri söz konusudur. Beşinci olarak, Aydınlanma Çağı nazarında edebiyat ve yazın alanında yine Alman dilinin yükselişi ifade edilen eksenin bir diğer boyutunu ihtiva etmektedir.

Son olarak, Soğuk Savaş döneminden bugüne Almanya özelinde kimlik odaklı tartışmalara bakıldığında benzer bir biçimde kültürel öğelere bakmak olanaklıdır. Zira çokkültürlülük üzerinden deklare edilen söylemler Alman kimliği adına dil-kültür faktörünün, entegrasyon adına başarı ya da başarısızlığın değerlendirilebilmesini mümkün kılmaktadır. Bu değerlendirmeler de kültürel bağlamın Alman kimliği inşası adına sahip olduğu etkiyi göstermektedir.

\section{KAYNAKÇA}

Becker-Cantarino, B. (Ed.) (2005). German Literature of the Eighteenth Century: The Enlightenment and Sensibility. Vol. 5, New York: Boydell \& Brewer.

Boas, F. (2017). Antropoloji ve Modern Yaşam. D. Uludağ (Çev.). Ankara: Doğu Batı Yayınları.

Bostan, H. (2016). Antropoloji, Kültür ve Güvenlik. Güvenlik Bilimleri Dergisi, 5 (2), ss. 1-31.

Breuilly, J. (2020). Avusturya, Prusya ve Almanya'nın Oluşumu, 1806-1871. A. Selman (Çev.). İstanbul: İletişim Yayınları.

Ceylan, Y. (2016). Çokkültürlülük Avrupa Modelleri (Almanya Örneği). Uluslararası Sosyal Araştırmalar Dergisi, Cilt. 9, Sayı. 43, ss. 1207-1215.

Çarpar, M. (2012). Çokkültürlü Bir Toplumda Antropolojinin Önemi. Folklor/Edebiyat, Cilt. 18, Say1. 70, ss. 47-66.

Doğan, F. (2019). Alman Milliyetçiliği, Milliyetçiliğin Coğrafyaları, Almanya, Fransa, İspanya, Romanya, İsrail, Misır, Japonya. G. Yücel (Ed.). Ankara: a Kitap, ss. 3-16.

Dorpalen, A. (1969). The German Struggle Against Napoleon: The East German View. The Journal of Modern History, Vol. 41, No. 4, ss. 485-516.

Eckardt, F. (2007). Multiculturalism in Germany: From Ideology to Pragmatism-and Back?. National Identities, Vol. 9, No. 3, ss. 235-245.

Eriksen, T. H. ve Nielsen, F. S. (2013). A History of Anthropology. New York: PlutoPress.

Fulbrook, M. (2018). Almanya'nın Kısa Tarihi. S Gürses (Çev.). İstanbul: Boğaziçi Üniversitesi Yayınevi.

Haviland, W. A. vd. (2008). Kültürel Antropoloji. İstanbul: Kaknüs Yayınlar1.

Hawes, J. (2019). Kısa Almanya Tarihi. Y. Alogan (Çev.). İstanbul: Say Yayınları.

İplikci, A. (2017). Johann Gottfried Herder'de Milliyetçilik Düşüncesi. Al-Farabi Uluslararası Sosyal Bilimler Dergisi, Vol. 1/1, ss. 126-135.

James, H. (1999). Alman Kimliği, 1770’den Bugüne. İ. Türkmen (Çev.). İstanbul: Kızılelma Yayıncilik.

Lavenda, R. H. ve Schultz, E. A. (2019). Kültürel Antropoloji, Temel Kavramlar. D. İşler ve O. Hayırlı (Çev.). Ankara: Doğu Batı Yayınları.

Levi-Strauss, C. (2018). Modern Dünyanın Sorunları Karşısında Antropoloji. A. Terzi (Çev.). İstanbul: Metis Yayınları.

Nordbruch, G. (2011). Germany: Migration, Islam and National Identity. Center for Mellemoststudier.

Ortaylı, İ. (2019). Osmanlı İmparatorluğu'nda Alman Nüfuzu. İstanbul: Kronik Kitap. 
Özbudun, S. ve Uysal, G. (2019). 50 Soruda Antropoloji. İstanbul: 7 Renk Basım Yayın ve Filmcilik.

Öztürk, A. O. (2015). Alman Oryantalizmi, 19. Yüzyıl Alman Halk kültüründe Türk Motifi. İstanbul: Vadi Yayınları.

Pamuk, İ. (2019). Almanya'da Kimlik, Aidiyet ve Türkiye Kökenli Öğrenciler. İstanbul: Yeni İnsan Yayınevi.

Sarukkai, S. (1997). The 'Other' in Anthropology and Philosophy. Economic and Politicak Weekly, ss. 1406-1409.

Scherr, A. (2013). The Construction of National Identity in Germany: "Migration Background" as a Political and Scientific Category. RCIS Working Paper, No. 2013/2.

Solsten, E. (1996). Germany, A Country Study. Federal Reseach Divison, Washington: Library of Congress.

Turner, T. (1993). Anthropology and Multiculturalism: What is Anthropology That Multiculturalists Should be Mindful of it?. Cultural Anthropology, 8 (4), ss. 411-429.

Waldow, A. ve DeSouza, N. (2017). Herder, Philosophy and Anthroplogy. Oxford University Press.

Wulf, C. (2015). Tarihsel Kültürel Antropoloji. Ö. D. Sarısoy (Çev.). Ankara: Dipnot Yayınları.

Yıldırım, F. (2011). Johann-Gottlieb Fichte'nin Devlet Anlayışı, Atatürk Üniversitesi, Sosyal Bilimler Enstitüsü, Felsefe Tarihi Anabilim Dalı, Yayımlanmamış Yüksek Lisans Tezi, Erzurum. 